\title{
40. STRONTIUM ISOTOPE STRATIGRAPHY OF THE OLIGOCENE-LOWER MIOCENE SECTION AT SITE 744, SOUTHERN INDIAN OCEAN ${ }^{1}$
}

\author{
Enriqueta Barrera, ${ }^{2}$ John Barron, ${ }^{3}$ and Alex Halliday ${ }^{2}$
}

\begin{abstract}
${ }^{87} \mathrm{Sr} /{ }^{86} \mathrm{Sr}$ ratios of well-preserved early Miocene-Oligocene planktonic foraminifers from Site 744 in the southern Indian Ocean provide the highest southern latitude $\mathrm{Sr}$ isotope record of this age. The isotopic data have been calibrated with the site magnetostratigraphy. ${ }^{87} \mathrm{Sr} /{ }^{86} \mathrm{Sr}$ ages were also determined using the $\mathrm{Sr}$ isotope-age equations of Miller et al. (1988) and Hess et al. (1989). There is good agreement between the calculated ages from ${ }^{87} \mathrm{Sr} /{ }^{86} \mathrm{Sr}$ measurements using these equations and those derived from magnetobiostratigraphy. In addition, these equations were useful for inference of sediment ages in intervals where the paleomagnetic record is not well resolved and the biostratigraphy is inconclusive. The Site $744{ }^{87} \mathrm{Sr} /{ }^{86} \mathrm{Sr}$ record can be used for correlation of Antarctic and low-latitude sequences and biostratigraphical zonation of foraminifers, radiolarians, diatoms, and calcareous nannofossils. This record will assist in the development of the high southern latitude biochronology.
\end{abstract}

\section{INTRODUCTION}

Site 744 of Ocean Drilling Program (ODP) Leg $119\left(61^{\circ} 34.6^{\prime} \mathrm{S}\right.$, $80^{\circ} 35.46^{\prime} \mathrm{E}$; water depth $2307.3 \mathrm{~m}$ ) provides the southernmost pelagic carbonate sequence of Neogene and late Paleogene age in the Indian Ocean (Fig. 1). Sediments at this site located on the southern end of the Kerguelen Plateau document the evolution of calcareous and siliceous planktonic organisms in the polar Indian Ocean (Barron et al., chapter 46, this volume), and the climate of East Antarctica and surrounding ocean from late Eocene time to present. The first occurrence of ice-rafted debris in lower Oligocene sediments, the progressive displacement of calcareous biogenic sediments by siliceous biogenic sediments in the lower to middle Miocene sequence, and the dominance of silicious biogenic sediments in the upper Miocene to Holocene section are indicative of the climatic and oceanographic changes that took place in the high southern latitudes during this time. These lithologic changes probably reflect the oceanographic response to the development of a major East Antarctic ice sheet in the early Oligocene, and increased glaciation on the continent during the middle and late Miocene. Such climatic events in the high latitudes must have affected global climatic patterns as well as the evolution of calcareous and siliceous zooplankton (foraminifers and radiolarians) and phytoplankton (nannofossils and diatoms) groups which are simultaneously represented throughout Oligocene and Miocene sediments at Holes 744A and 744B.

The study of the paleoceanography and biology of the polar Indian Ocean and their relation to that of the low latitude oceans during the late Paleogene and Neogene requires that microfossil and climatic events be calibrated to an absolute time scale. However, tropical and subtropical planktonic foraminifer zonations and traditional calcareous nannofossil zonations are not applicable to the biostratigraphy of Site 744 because biostratigraphic marker species are often rare or absent (Huber, chapter 24 , this volume; Wei and Thierstein, this volume). Diatom and radiolarian biostratigraphies of mid- or low-latitude

\footnotetext{
${ }^{1}$ Barron, J., Larsen, B., et al., 1991. Proc. ODP, Sci. Results, 119: College Station, TX (Ocean Drilling Program).

2 Department of Geological Sciences, The University of Michigan, Ann Arbor, MI 48103, U.S.A.

${ }^{3}$ U.S. Geological Survey, 345 Middlefield Road, Menlo Park, CA 94025,
}

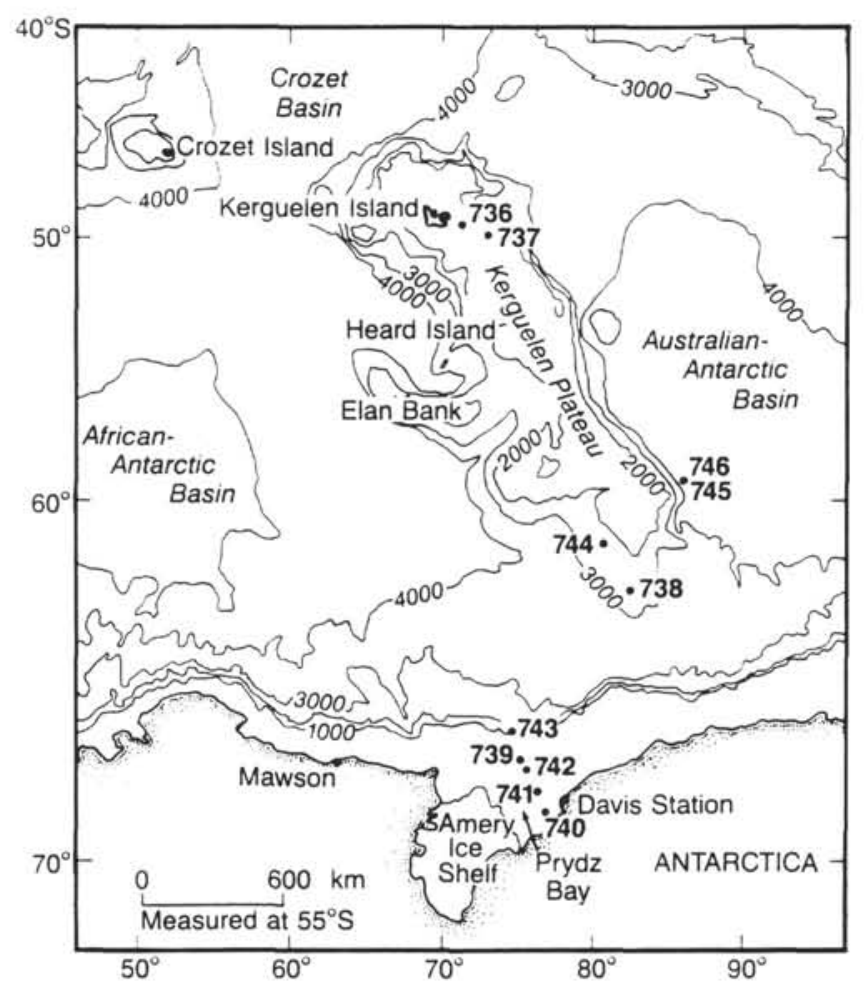

Figure 1. Location of Site 744 on the southern Kerguelen Plateau and other sites drilled during Leg 119.

regions can be applied at Site 744 (Baldauf and Barron, this volume; Caulet, this volume; Barron et al., chapter 46, this volume), but it is not obvious that zonal boundaries are synchronous across latitudes. Stratigraphic correlation using stable isotope compositions of biogenic carbonate has been used for low-latitude sequences. However, this type of correlation which depends upon matching patterns of $\delta^{13} \mathrm{C}$ and $\delta^{18} \mathrm{O}$ change cannot be used successfully across latitudes in the Oligocene and early Miocene because the climate and oceanography of the southern Indian Ocean appear to have been decoupled from that of the low-latitude Atlantic and Pacific Oceans at this time 
(Barrera and Huber, this volume). Paleomagnetic stratigraphy which provides absolute ages is also dependent on biostratigraphy for age assignment to specific levels within the magnetic succession.

Recently, Sr isotope stratigraphy has proved a useful tool for the correlation of carbonate sediments within and across latitudes because the ${ }^{87} \mathrm{Sr} /{ }^{86} \mathrm{Sr}$ ratio of normal seawater at any given time appears to be uniform (Burke et al., 1982; DePaolo and Ingram, 1985). Moreover, the ${ }^{87} \mathrm{Sr} /{ }^{86} \mathrm{Sr}$ of seawater, as inferred from the measured ratio of marine carbonates, has varied significantly through time (Burke et al., 1982). Consequently, the greatest chronological resolution is obtained with samples deposited when the ${ }^{87} \mathrm{Sr} /{ }^{86} \mathrm{Sr}$ ratio of seawater changed rapidly and nearly monotonically, as in the late Paleogene and early Neogene. In this paper, $\mathrm{Sr}$ isotope data of early middle Miocene to early Oligocene planktonic foraminifers from Site 744 have been calibrated with the magnetostratigraphy of this site. Site 744 ${ }^{87} \mathrm{Sr} /{ }^{86} \mathrm{Sr}$ ratios have also been compared to the following data sets: (1) the ${ }^{87} \mathrm{Sr} /{ }^{86} \mathrm{Sr}$ data from lower Miocene sediments of Deep Sea Drilling Project (DSDP) Site 590 (DePaolo, 1986), and (2) those of lower Miocene and Oligocene sediments of DSDP Sites 516, 563 (Hess et al., 1989), and 522 (Miller et al., 1988). Integration of $\mathrm{Sr}$ isotope data with the magnetostratigraphy of Site 744 allows more precise absolute dating than the use of one of these techniques alone, and permits dating of biostratigraphic datum and paleoclimatic events in the southern Indian Ocean.

\section{BACKGROUND}

The ${ }^{87} \mathrm{Sr} /{ }^{86} \mathrm{Sr}$ ratio of seawater is determined by the proportion of $\mathrm{Sr}$ entering the ocean from two sources that have very characteristic ratios, the continental crust and the upper mantle (Elderfield, 1986). Because the residence time of $\mathrm{Sr}$ in the ocean has been estimated at about 5 m.y., whereas the ocean mixes in approximately 1,000 yr (Broecker and Peng, 1982), the ${ }^{87} \mathrm{Sr} /{ }^{86} \mathrm{Sr}$ ratio of seawater is uniform at a given time. Within the last 100 m.y., variations in the flux of $\mathrm{Sr}$ from hydrothermal reactions in ocean ridges and $\mathrm{Sr}$ derived from recycling of old carbonates are considered responsible for the observed long-term variations in the seawater ${ }^{87} \mathrm{Sr} /{ }^{86} \mathrm{Sr}$ record (Palmer and Elderfield, 1985; Hess et al., 1986). Burke et al. (1982) published the first detailed record for this time period and the entire Phanerozoic from analyses of bulk carbonate samples, where it was evident that a rapid and apparent monotonic increase in seawater ${ }^{87} \mathrm{Sr} /{ }^{86} \mathrm{Sr}$ occurred in the second half of the Cenozoic, whereas little variation is observed in the older part of the Cenozoic. Further refinement of the Cenozoic record has revealed that the highest chronologic resolution can be obtained with samples from the Oligocene and early Miocene (DePaolo and Ingram, 1985; Palmer and Elderfield, 1985; DePaolo, 1986; Hess et al., 1986; Miller et al., 1988). The data of DePaolo (1986) for bulk carbonate samples from Site 590 show that the rapid change in the early Miocene was followed, at about $16 \mathrm{Ma}$, by a two-step gentle increase in ${ }^{87} \mathrm{Sr} /{ }^{86} \mathrm{Sr}$ ratios during the middle and late Miocene. The first two ${ }^{87} \mathrm{Sr} /{ }^{86} \mathrm{Sr}$ records calibrated directly to the geomagnetic time scale were those for the Oligocene sections of Contensa Quarry and DSDP Site 522 (DePaolo and Ingram, 1986; Miller et al., 1988). The more detailed record of planktonic foraminifers from Site 522 by Miller et al. (1988) indicates that the rate of change was greater for the late Oligocene than for the early Oligocene through the latest Eocene at about 38 Ma. Recently, Hess et al. (1989) have presented ${ }^{87} \mathrm{Sr} /{ }^{86} \mathrm{Sr}$ data of well-preserved planktonic foraminifer from the lower Miocene and Oligocene sections at DSDP Sites 516 and 563, which are two of the four sites with magnetostratigraphy on which Berggren et al. (1985a, 1985b) elaborated their magnetobiostratigraphic model. The data from these two sites reveal that the rate of change of ${ }^{87} \mathrm{Sr} /{ }^{86} \mathrm{Sr}$ increased at about $27 \mathrm{Ma}$ and did not vary during the rest of the late Oligocene and early Miocene. Equations derived from the two relations of ${ }^{87} \mathrm{Sr} /{ }^{86} \mathrm{Sr}$ and age (for samples older or younger than $27 \mathrm{Ma}$ ), have been used by Hess et al., to estimate ages of sediments at four other DSDP sites (without magnetostratigraphy), and to determine from these data the synchroneity of biostratigraphic datums oceanwide across longitude.

\section{METHODS}

Sediment samples were disaggregated in tap water, washed over a $63-\mu \mathrm{m}$ screen, and dried in the screen placed over a hotplate set at about $50^{\circ} \mathrm{C}$. Samples for $\mathrm{Sr}$ isotope analysis and determination of $\mathrm{Sr}$ and $\mathrm{Ca}$ concentration consisted of specimens larger than $150 \mu \mathrm{m}$ of mixed species of planktonic foraminifers and the planktonic foraminifer Globorotaloides suteri, respectively. Particles adhering to foraminifers were removed by ultrasonic agitation of tests in distilled water. For $\mathrm{Sr}$ isotope analysis, the dry sample weighing about $1 \mathrm{mg}$ was dissolved in a 5-M solution of acetic acid. Sr was separated by standard ion exchange procedures using $2.5-\mathrm{N} \mathrm{HCl}$. Sr was loaded onto a rhenium filament with $\mathrm{Ta}_{2} \mathrm{O}_{5}$ and the isotopic composition determined using a VG Sector multicollector mass spectrometer in the radiogenic isotope laboratory of The University of Michigan. To correct for mass discrimination, measured values were normalized to a ${ }^{86} \mathrm{Sr} /{ }^{88} \mathrm{Sr}$ ratio of 0.1194 . The mean average difference in ${ }^{87} \mathrm{Sr} /$ ${ }^{86} \mathrm{Sr}$ ratios of duplicate measurements of the same sample was 0.000014 . The ${ }^{87} \mathrm{Sr} /{ }^{86} \mathrm{Sr}$ ratio of the standard NBS- 987 averaged $0.710245 \pm 13$. The mean value of 28 measurements of modern seawater USGS EN-1 standard is $0.709179 \pm 14$.

For $\mathrm{Sr}$ and $\mathrm{Ca}$ concentration measurements, tests of $G$. suteri were crushed with a glass rod and fragments were ultrasonically agitated in distilled water to remove adhering and infilling finegrained material. After each rinse, the supernatant was pipetted out. Dry samples between 100 and $50 \mu \mathrm{g}$ were reacted with $10 \%$ $\mathrm{HCl}$ and the solution was analyzed in simultaneous mode in a Leemans Lab Inc. Plasma-Spec III model. Precision of duplicate samples was better than $5 \%$. $\mathrm{Sr} / \mathrm{Ca}$ ratios are reported in $10^{-3}$ moles. Absolute ages for Site 744 were calculated using the linear relation equation of Miller et al. (1988) based on Oligocene ${ }^{87} \mathrm{Sr} /{ }^{86} \mathrm{Sr}$ ratios of Site 522 ,

$$
\text { Age }(\mathrm{Ma})=20392.79-28758.84\left({ }^{87} \mathrm{Sr} /{ }^{86} \mathrm{Sr}\right) \text {, }
$$

and the equation of Hess et al. (1989),

$$
t=-0.24742 \delta^{87} \mathrm{Sr}-10.95385,
$$

for samples older than $27 \mathrm{Ma}$, and

$$
t=-0.14359 \delta^{87} \mathrm{Sr}+4.92651
$$

for samples younger than $27 \mathrm{Ma} . \delta^{87} \mathrm{Sr}$ is the per 100,000 deviation of the ${ }^{87} \mathrm{Sr} /{ }^{86} \mathrm{Sr}$ ratio of the sample from that of modern seawater. Age uncertainty is $\pm 0.38 \mathrm{~m}$.y. and $\pm 0.31 \mathrm{~m}$.y. for the first equation and the second equation of Hess et al. (1989).

\section{PRESERVATION OF FORAMINIFER ${ }^{87} \mathrm{Sr} /{ }^{86} \mathrm{Sr}$ RATIO}

Dissolution and reprecipitation processes in foraminifer calcite can significantly modify foraminifer $\mathrm{Sr}$ isotope composition if pore waters have received $\mathrm{Sr}$ from a source with a ${ }^{87} \mathrm{Sr} /{ }^{86} \mathrm{Sr}$ ratio very different from that of the foraminifers. Secondary calcite replacement of the foraminifer in pore waters with ${ }^{87} \mathrm{Sr} /{ }^{86} \mathrm{Sr}$ ratios similar to those of coexisting foraminifers will cause little or no modification to the original foraminifer ${ }^{87} \mathrm{Sr} /{ }^{86} \mathrm{Sr}$ ratio. However, interstitial waters with ratios different from the coex- 
isting carbonate can result from $\mathrm{Sr}$ input from (1) underlying basalt and (2) volcanic ash and glass with relatively low ${ }^{87} \mathrm{Sr} /$ ${ }^{86} \mathrm{Sr}$ ratios (Elderfield and Gieskes, 1982; Gieskes et al., 1986), and (3) older or younger carbonates within the sedimentary column. Consequently, in the assessment of the preservation of the original foraminifer ${ }^{87} \mathrm{Sr} /{ }^{86} \mathrm{Sr}$ ratio, data on the ${ }^{87} \mathrm{Sr} /{ }^{86} \mathrm{Sr}$ ratio of pore waters is important if there is evidence for secondary overgrowth or replacement in the foraminifer test. This can be evaluated by scanning electron microscope (SEM) inspection of the wall surfaces and microstructure of tests. Preservation of the foraminifer chemistry has also been inferred from $\mathrm{Sr} / \mathrm{Ca}$ ratios of pore waters and/or the foraminifer (Baker et al., 1982; Elderfield et al., 1982). According to the experimentally determined distribution coefficient of $\mathrm{Sr}$, abiologically precipitated calcite has lower $\mathrm{Sr} / \mathrm{Ca}$ ratios than biologically precipitated calcite (Katz et al., 1972; Baker et al., 1982). Consequently, it is commonly inferred that $\mathrm{Sr} / \mathrm{Ca}$ ratios of foraminiferal tests close to those measured in well-preserved specimens indicate little or no diagenetic alteration by dissolution-reprecipitation processes (Hess et al., 1986, 1989).

SEM observations of specimens of selected planktonic foraminifer species were made at several levels within the lower Miocene-Oligocene section at Site 744. Evidence for solution is ubiquitous in planktonic foraminifer tests as illustrated in SEM images of $G$. suteri in Plate 1 . This species is relatively abundant in upper Eocene and Oligocene sediments at Site 744 (Huber, chapter 24 , this volume). Major solution features include cavities within walls (Pl. 1, Figs. 3 and 4) and removal of portions of the exterior surface layer of tests (PI. 1, Fig. 2). The amount of calcite added to tests by reprecipitation processes appears to be volumetrically small in relation to the whole. Secondary calcite is evident as small euhedral crystals on interior surfaces ( $\mathrm{Pl}$. 1, Fig. 3), which increase in size with age. Neither interstitial waters ${ }^{87} \mathrm{Sr} /{ }^{86} \mathrm{Sr}$ nor $\mathrm{Sr} / \mathrm{Ca}$ ratios for Site 744 are available to assess the extent of modification of foraminifer chemistries. However, $\mathrm{Sr} / \mathrm{Ca}$ ratios of Site $744 \mathrm{G}$. suteri, a near-surface water dweller (Barrera and Huber, this volume), are between 1.2 and $1.5 \times 10^{-3}$ moles (Table 1). This is either slightly lower or in the range of those measured (between 1.3 and $1.6 \times 10^{-3}$ moles) for modern planktonic foraminifers with approximately the same depth habitat in the water column (Delaney, 1985). This suggests either none or minor modification of the foraminifer $\mathrm{Sr}$ concentrations occurred. Moreover, based on the consistency of the ${ }^{87} \mathrm{Sr} /{ }^{86} \mathrm{Sr}$ data discussed below and the apparent lack of textural evidence for major secondary calcite replacement features, we consider ${ }^{87} \mathrm{Sr} /{ }^{86} \mathrm{Sr}$ ratios reported here to be similar to those of contemporaneous seawater.

\section{RESULTS AND DISCUSSION}

$\mathrm{Sr}$ isotope ratios of Site 744 are listed in Table 1. Two sets of ages are estimated for Site 744 foraminifer samples. One group of ages (Table 1) is derived from interpolation between depthages of magnetochrons (Keating, this volume; Barron et al., chapter 46 , this volume) whose ages are obtained using the magnetobiostratigraphic model of Berggren et al. (1985a, 1985b) (Fig. 2B). For samples from Hole 744B (Table 1), ages are estimated by comparison of our data with the bulk carbonate ${ }^{87} \mathrm{Sr} /$ ${ }^{86} \mathrm{Sr}$ ratios of Site 590 (DePaolo, 1986) (Table 2, Fig. 3). Ages for Site 590 are based on those of calcareous nannofossil datums (Lohmann, 1985) revised using the time scales of Berggren et al. (1985b) and Barron et al. (1985) (Tables 2 and 3). Ages of samples in Hole 744A (Table 1) were calculated using the age equations derived (1) by Hess et al. (1989) from the ${ }^{87} \mathrm{Sr} /{ }^{86} \mathrm{Sr}$-age relations at DSDP Sites 516 and 563, and (2) by Miller et al. (1988) from the ${ }^{87} \mathrm{Sr} /{ }^{86} \mathrm{Sr}$-age relation at Site 522 (Fig. 3).

Table 1. $\mathrm{Sr} / \mathrm{Ca}$ and ${ }^{87} \mathrm{Sr} /{ }^{86} \mathrm{Sr}$ ratios and estimated ages of mixed planktonic foraminifer samples from Holes $744 \mathrm{~A}$ and $744 \mathrm{~B}$.

\begin{tabular}{|c|c|c|c|c|c|c|c|}
\hline $\begin{array}{l}\text { Core, section, } \\
\text { interval }(\mathrm{cm})\end{array}$ & $\begin{array}{l}\text { Depth } \\
\text { (mbsf) }\end{array}$ & $\begin{array}{c}\mathrm{Sr} / \mathrm{Ca} \\
\left(10^{-3} \text { moles }\right)\end{array}$ & ${ }^{87} \mathrm{Sr} /{ }^{86} \mathrm{Sr}$ & 2-sigma & $\begin{array}{l}\mathrm{Age}^{\mathrm{a}} \\
(\mathrm{Ma})\end{array}$ & $\begin{array}{l}\mathrm{Age}^{\mathrm{b}} \\
(\mathrm{Ma})\end{array}$ & $\begin{array}{l}\mathrm{Age}^{\mathrm{c}} \\
\text { (Ma) }\end{array}$ \\
\hline \multicolumn{8}{|l|}{ 119-744B- } \\
\hline $7 \mathrm{H}-7,70-72$ & 59.71 & & 0.708762 & 14 & 14.8 & 15.9 & \\
\hline $8 \mathrm{H}-1,60-62$ & 60.11 & & 0.708768 & 13 & 14.9 & 15.9 & \\
\hline $8 \mathrm{H}-3,60-62$ & 63.11 & & 0.708748 & 17 & 15.7 & 16.1 & \\
\hline $8 \mathrm{H}-5,60-62$ & 66.11 & & 0.708690 & 18 & 16.6 & 17.0 & \\
\hline $9 \mathrm{H}-1,58-60$ & 69.59 & & 0.708661 & 17 & 17.3 & 17.6 & \\
\hline $9 \mathrm{H}-4,58-60$ & 74.09 & & 0.708635 & 18 & 17.8 & 18.0 & \\
\hline $9 \mathrm{H}-6,58-60$ & 77.09 & & 0.708629 & 14 & 18.1 & 18.1 & \\
\hline \multicolumn{8}{|l|}{$119-744 \mathrm{~A}-$} \\
\hline $10 \mathrm{H}-1,95-100$ & 81.13 & & 0.708518 & 17 & 18.8 & 18.7 & \\
\hline $10 \mathrm{H}-\mathrm{CC}$ & 89.13 & & 0.708435 & 16 & 20.1 & 20.4 & \\
\hline $11 \mathrm{H}-2,100-105$ & 92.13 & & 0.708389 & 17 & 20.4 & 21.3 & \\
\hline $11 \mathrm{H}-4,100-105$ & 95.13 & & 0.708391 & 14 & 21.0 & 21.3 & \\
\hline $11 \mathrm{H}-6,100-105$ & 98.13 & 1.45 & 0.708242 & 16 & ? & 24.3 & 24.6 \\
\hline $12 \mathrm{H}-2,96-101$ & 101.67 & 1.32 & 0.708163 & 16 & 26.6 & 25.9 & 26.8 \\
\hline $12 \mathrm{H}-4,95-100$ & 104.67 & 1.24 & 0.708156 & 16 & 26.8 & 26.0 & 27.0 \\
\hline $12 \mathrm{H}-5,95-100$ & 106.17 & 1.34 & 0.708121 & 17 & 27.2 & 26.7 & 28.0 \\
\hline $13 \mathrm{H}-5,95-100$ & 115.67 & 1.33 & 0.708082 & 18 & 28.2 & 28.0 & 29.0 \\
\hline $13 \mathrm{H}-\mathrm{CC}$ & 118.2 & & 0.708013 & 13 & $?$ & 30.4 & 31.1 \\
\hline $14 \mathrm{H}-2,95-100$ & 120.67 & & 0.707960 & 11 & 32.3 & 32.2 & 32.7 \\
\hline $14 \mathrm{H}-5,95-100$ & 125.17 & & 0.707911 & 11 & 32.9 & 33.9 & 34.0 \\
\hline $15 \mathrm{H}-1,95-100$ & 128.67 & 1.23 & 0.707916 & 17 & 33.8 & 33.8 & 33.9 \\
\hline $15 \mathrm{H}-5,95-100$ & 134.67 & & 0.707873 & 14 & 34.7 & 35.3 & 35.2 \\
\hline $16 \mathrm{H}-6,95-100$ & 145.67 & & 0.707838 & 18 & 35.9 & 36.5 & 36.2 \\
\hline $18 \mathrm{H}-1,95-100$ & 148.57 & 1.38 & 0.707778 & 13 & 36.3 & 38.6 & 37.9 \\
\hline
\end{tabular}

Note: ? indicates uncertain age due to presence of hiatus.

a Ages estimated from magnetobiostratigraphy (Barron et al., chapter 46, this volume).

${ }^{b}$ Ages estimated from comparison of Sr isotopic data from Site 590 (DePaolo, 1986) and using

equations of Hess et al. (1989) as explained in text.

c Ages estimated using equation of Miller et al. (1988) as explained in text. 

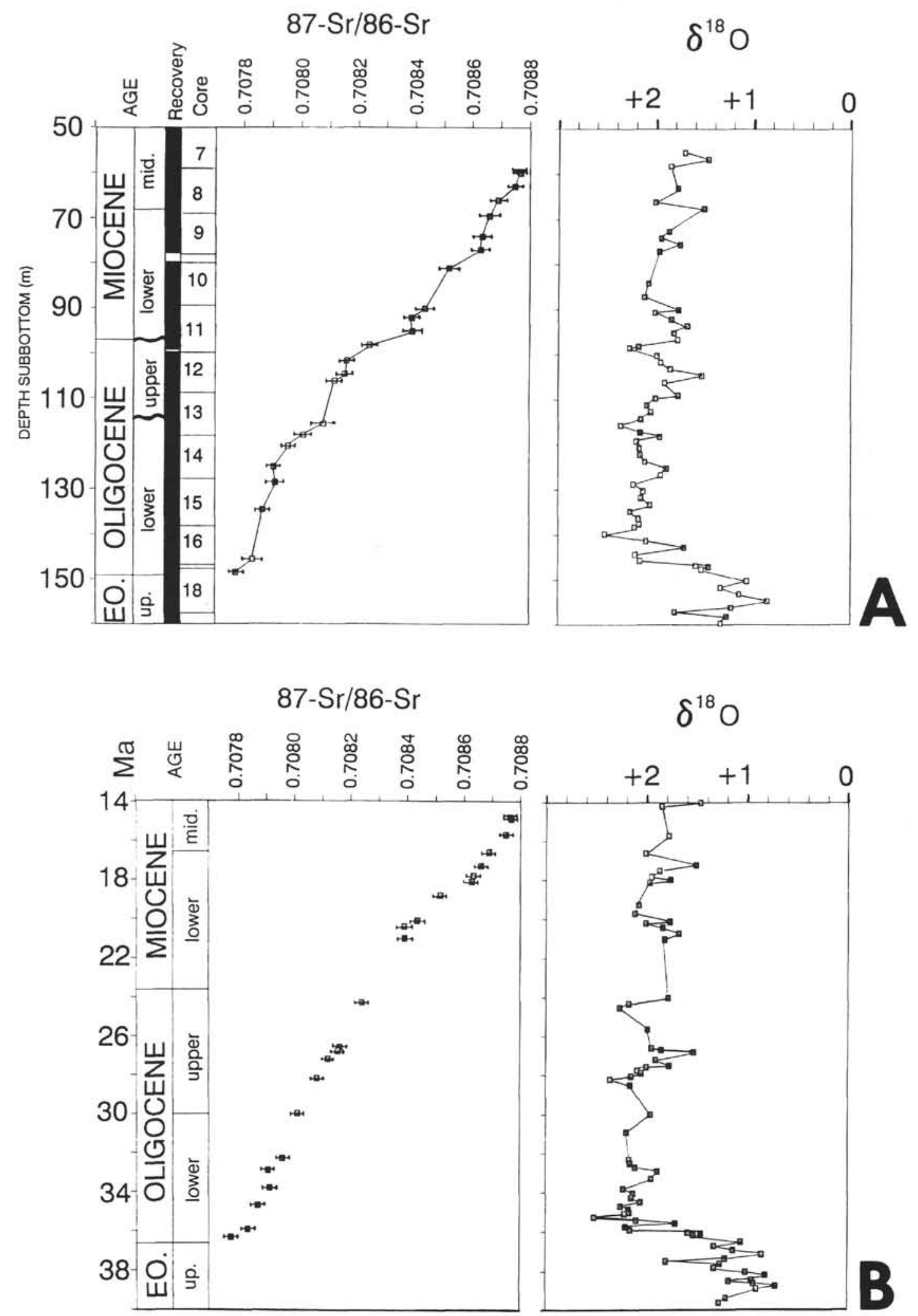

Figure 2. A. ${ }^{87} \mathrm{Sr} /{ }^{86} \mathrm{Sr}$ ratios of mixed planktonic foraminifer samples and $\delta^{18} \mathrm{O}$ values of the benthic foraminifer Cibicidoides from Site 744 plotted vs. depth in the sediment. $\delta^{18} \mathrm{O}$ data from Barrera and Huber (this volume). Wavy lines in the stratigraphic column indicate major hiatuses. B. ${ }^{87} \mathrm{Sr} /{ }^{86} \mathrm{Sr}$ ratios of mixed planktonic foraminifer samples and $\delta^{18} \mathrm{O}$ values of Cibicidoides from Site 744 plotted vs. sediment age. 
Table $2 .{ }^{87} \mathrm{Sr} /{ }^{86} \mathrm{Sr}$ ratios of bulk samples and estimated ages of sediments from Site 590.

\begin{tabular}{ccrrr}
\hline $\begin{array}{c}\text { Core, } \\
\text { section }\end{array}$ & $\begin{array}{c}\text { Depth } \\
\text { (mbsf) }\end{array}$ & $\begin{array}{r}\mathrm{Age}^{\mathrm{a}} \\
(\mathrm{Ma})\end{array}$ & $\begin{array}{l}\mathrm{Age}^{\mathrm{b}} \\
(\mathrm{Ma})\end{array}$ & ${ }^{87} \mathrm{Sr} /{ }^{86} \mathrm{Sr}^{\mathrm{c}}$ \\
\hline $25-1$ & 224 & 5.7 & 5.6 & 0.709031 \\
$30-3$ & 272 & 6.2 & 6.4 & 0.709024 \\
$33-2$ & 300 & 7.7 & 7.0 & 0.709016 \\
$35-5$ & 323 & 9.2 & 7.3 & 0.708992 \\
$36-4$ & 332 & 9.7 & 7.7 & 0.708978 \\
$37-4$ & 341 & 10.2 & 8.1 & 0.708975 \\
$38-6$ & 354 & 10.8 & 8.8 & 0.708990 \\
$40-6$ & 373 & 11.8 & 9.6 & 0.708958 \\
$41-6$ & 383 & 12.1 & 10.7 & 0.708960 \\
$42-6$ & 393 & 12.4 & 11.3 & 0.708926 \\
$43-4$ & 399 & 12.5 & 11.6 & 0.708895 \\
$44-5$ & 410 & 12.8 & 12.4 & 0.708892 \\
$45-5$ & 421 & 13.3 & 13.1 & 0.708889 \\
$46-6$ & 430 & 14.3 & 13.6 & 0.708889 \\
$47-4$ & 436 & 14.9 & 14.0 & 0.708870 \\
$48-5$ & 448 & 15.9 & 15.0 & 0.708858 \\
$49-4$ & 459 & 16.5 & 15.8 & 0.708848 \\
$50-2$ & 463 & 17.0 & 16.3 & 0.708792 \\
$51-5$ & 477 & 18.8 & 18.0 & 0.708606 \\
$52-5$ & 487 & 19.5 & 18.9 & 0.708558 \\
$53-1$ & 491 & 19.9 & 19.3 & 0.708544 \\
$53-7$ & 498 & 20.7 & 20.0 & 0.708522 \\
& & & & \\
\hline & & &
\end{tabular}

${ }^{\text {a }}$ Ages reported in DePaolo (1986) based on nannofossil datum levels (Lohman, 1986).

${ }^{b}$ Estimates based on reassignment of ages to nannofossil datum levels (Lohman, 1986) using Berggren et al. (1985b) and Barron et al. (1985) time scales.

${ }^{\mathrm{c}}$ Ratios reported in DePaolo (1986).
Table 3. Ages and depths of nannofossil datums from Site $\mathbf{5 9 0}$.

\begin{tabular}{lrc}
\hline \multicolumn{1}{c}{ Nannofossil Datum } & $\begin{array}{c}\text { Age } \\
\text { (Ma) }\end{array}$ & $\begin{array}{c}\text { Depth } \\
\text { (mbsf) }\end{array}$ \\
\hline FO Amaurolithus primus & 6.5 & $271.76-273.26$ \\
FO Discoaster quinqueramus & 7.3 & $322.76-326.30$ \\
LO Discaster hamatus & 8.8 & $351.56-355.10$ \\
LO Catinaster colitus & 8.9 & $355.10-364.70$ \\
FO Discoaster hamatus & 10.0 & $374.30-380.36$ \\
FO Catinaster colitus & 10.8 & $383.90-383.96$ \\
LO Cyclicargolithus floridanus & 11.6 & $393.50-403.10$ \\
LO Sphenolithus heteromorphus & 14.0 & $434.96-437.96$ \\
FO Discoaster exilis & 15.9 & $460.70-460.76$ \\
LO Sphenolithus belemnos & 17.4 & $470.30-470.36$ \\
FO Sphenolithus heteromorphus & 17.5 & $470.30-470.36$ \\
LO Triquetrorhabdulus carinatus & 18.7 & $485.96-489.50$ \\
FO Discoaster druggii & 19.5 & $489.56-492.56$ \\
\hline
\end{tabular}

Note: $\mathrm{FO}=$ first occurrence; $L O=$ last occurrence. Nannofossil datums from Lohman (1986). Ages are assigned based on Berggren et al. (1985a) and Barron et al. (1985) time scales.

${ }^{87} \mathrm{Sr} /{ }^{86} \mathrm{Sr}$ ratios of Site 744 samples consistently increase with decreasing sample depth and age (Fig. 2A and 2B). This pattern is typical of deep-sea sedimentary sequences of this age which have not been extensively affected by reworking or dissolution and reprecipitation processes (Hess et al., 1989). The increase in ${ }^{87} \mathrm{Sr} /{ }^{86} \mathrm{Sr}$ ratios is greater in the lower Miocene part of the section than in the Oligocene, which is similar to that observed at other deep-sea sequences (Hess et al., 1989). Estimates from the $\mathrm{Sr}$ isotope-age relation of Site 590 yield ages between about 15.9

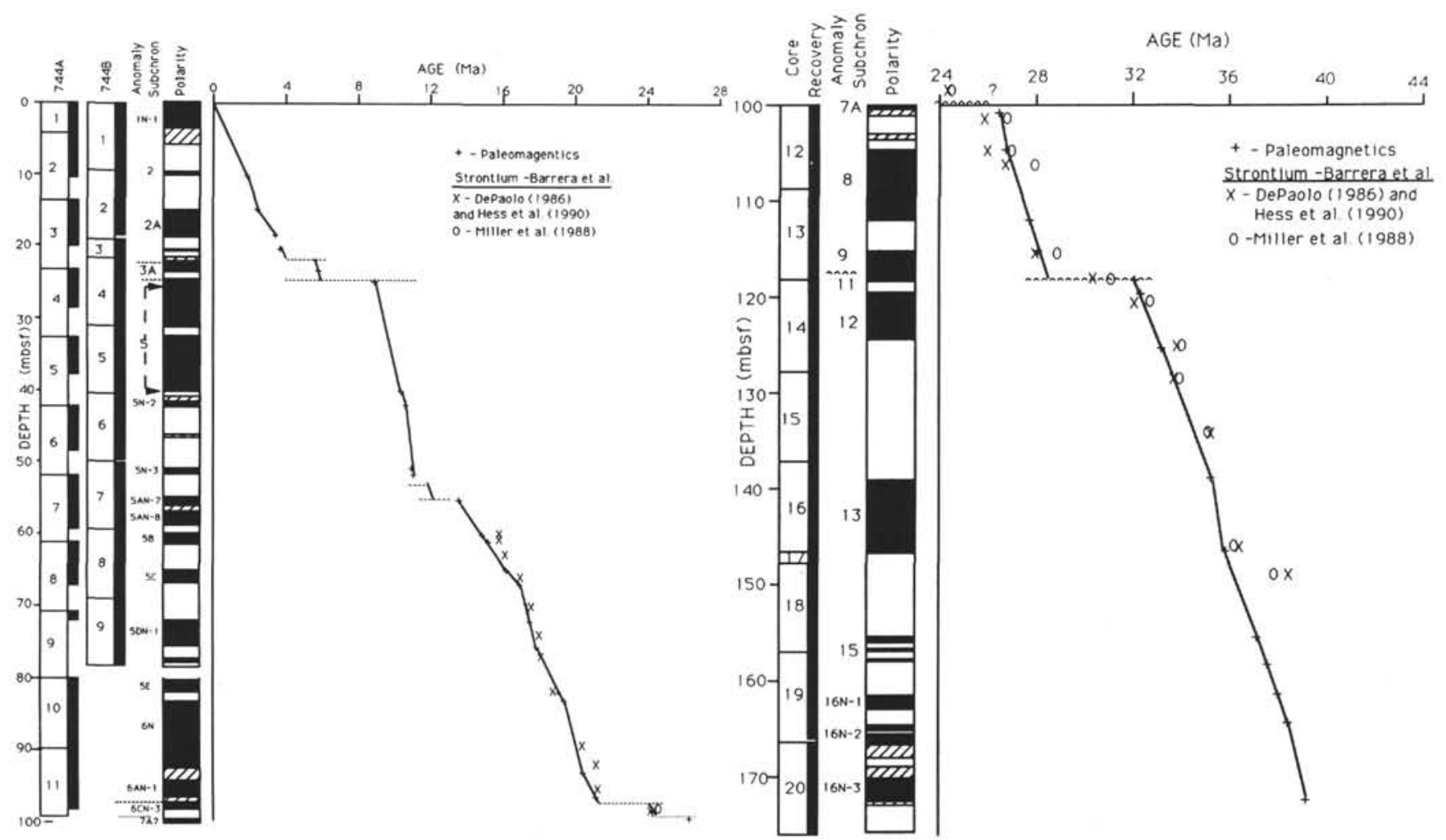

Figure 3. Age vs. depth plots of the Neogene and Paleogene sections cored at Site 744 utilizing magnetostratigraphic $(+)$, strontium isotopes $(\mathrm{X}, \mathrm{O})$, and biostratigraphic (Barron et al., chapter 46, this volume) events. Diagonal lines in the polarity section indicate intervals of uncertainty or lack of study. Wavy lines represent hiatuses. Ages of Site $744{ }^{87} \mathrm{Sr} /{ }^{86} \mathrm{Sr}$ samples were estimated by (1) comparison of ratios shallower than $80 \mathrm{mbsf}$ with those from Site 590, and (2) using the Sr isotope-age equations of Hess et al. (1989) and Miller et al. (1988) as described in the text. 
and 18.1 Ma for Hole 744B samples (Table 1, Fig. 3). These ${ }^{87} \mathrm{Sr} /{ }^{86} \mathrm{Sr}$ ages are in fairly good agreement with magnetostratigraphically derived ages, except for those for the two uppermost Samples 119-744B-7H-7, 70-72 cm, and 119-744B-8H-1, 60-62 $\mathrm{cm}$. Magnetobiostratigraphy suggests ages about $1 \mathrm{~m}$.y. younger than $\mathrm{Sr}$ isotope ages of $15.9 \mathrm{Ma}$ for the uppermost samples (Table 1, Fig 3). The reason for this age inconsistency is not obvious. Reworking of older foraminifer tests into younger sediments could explain the older ages, but there is no micropaleontological evidence to support this scenario (Huber, chapter 24, this volume; Barron et al., chapter 46 , this volume). The small discrepancy between ages of other samples, with $\mathrm{Sr}$ isotope yielding slightly older ages relative to magnetosbiostratigraphy (Table 1), could be due to the gap in the ${ }^{87} \mathrm{Sr} /{ }^{86} \mathrm{Sr}$ record of Site 590 in the period from about 16.3 to $18 \mathrm{Ma}$ that does not permit direct comparison with data points (Table 2). Published foraminifer data of this age (from sites without magnetostratigraphy) have ratios in the range of those interpolated for Site 590 (Hess et al., 1986). The discrepancy in assigned ages of Site 744 ${ }^{87} \mathrm{Sr} /{ }^{86} \mathrm{Sr}$ ratios based on magnetostratigraphy and those from comparison with Site $590{ }^{87} \mathrm{Sr} /{ }^{86} \mathrm{Sr}$ ratios could be due to diachroneity between low-latitude and Site 590 faunal datums in the Miocene.

Magnetobiostratigraphic ages of Hole 744A are likewise in general good agreement with those estimated using the $\mathrm{Sr}$ isotope-age equations of Hess et al. (1989) and Miller et al. (1988) (Table 1, Fig. 3). Exceptions are Samples 119-744A-10H-CC, $119-744 \mathrm{~A}-14 \mathrm{H}-5,95-100 \mathrm{~cm}$, and $119-744 \mathrm{~A}-18 \mathrm{H}-1,95-100 \mathrm{~cm}$, for which magnetobiostratigraphy assigned ages are younger by at least $1 \mathrm{~m} . \mathrm{y}$. in comparison to ${ }^{87} \mathrm{Sr} /{ }^{86} \mathrm{Sr}$ ages. Reworking of older foraminifers has not been noted at these levels (Huber, chapter 24 , this volume), and textural evidence and foraminifer $\mathrm{Sr} / \mathrm{Ca}$ ratios do not indicate large amounts of secondary calcite in foraminifer tests. Therefore, ${ }^{87} \mathrm{Sr} /{ }^{86} \mathrm{Sr}$ ratios of these samples probably reflect the isotopic composition of contemporaneous seawater. The age agreement between magnetobiostratigraphy and either one of the $\mathrm{Sr}$ isotope-age equations appears to be independent of sample age. However, age estimates using the equation of Miller et al. (1988) are significantly older ages than those calculated by the equation of Hess et al. (1989) for samples younger than about $34 \mathrm{Ma}$ (Table 1, Fig. 3). The largest difference between the ages calculated by these equations is for ${ }^{87} \mathrm{Sr} /{ }^{86} \mathrm{Sr}$ ratios of early late Oligocene sediments.

$\mathrm{Sr}$ isotope ages were also used to confirm the presence of hiatuses in the Hole 744A section as suggested by magnetostratigraphy and biostratigraphy. The first hiatus located within the lower part of Core 119-744A-11H and between Samples 119$744 \mathrm{~A}-11-5,63-65 \mathrm{~cm}$, and 119-744A-11-5, 92-93 cm, spans the early Miocene-Oligocene boundary according to diatom biostratigraphy (Baldauf and Barron, this volume) and interpretation of magnetostratigraphy (Barron et al., chapter 46, this volume). $\mathrm{Sr}$ isotope ages of sediments above and below this unconformity based on the equation of Hess et al. (1989) suggest that about 2 to 3 m.y. may be missing from the sedimentary record in this interval (Table 1, Fig. 3). Another hiatus may be present at or near the core break between Cores 119-744A-11H and 119$744 \mathrm{~A}-12 \mathrm{H}$ based on interpretation of the magnetic polarity stratigraphy (Fig. 3). ${ }^{87} \mathrm{Sr} /{ }^{86} \mathrm{Sr}$ ages of Samples $119-744 \mathrm{~A}-11 \mathrm{H}-6$, $100-105 \mathrm{~cm}$, and $119-744 \mathrm{~A}-12 \mathrm{H}-2,96-101 \mathrm{~cm}$, across the core break indicate that this hiatus spans approximately $1 \mathrm{~m}$.y. (Table 1, Fig. 3).

Evidence from ${ }^{87} \mathrm{Sr} /{ }^{86} \mathrm{Sr}$ and $\delta^{18} \mathrm{O}$ results and biostratigraphy indicate major hiatuses at or near the early-late Oligocene boundary at Site $744 .{ }^{87} \mathrm{Sr} /{ }^{86} \mathrm{Sr}$ age estimates using the equation of Hess et al. (1989) indicate that sediments in the intervals from 28 (115.67 mbsf) to $30.4 \mathrm{Ma}$ (118.2 mbsf) and from 30.4 to 32.2 Ma (120.67 mbsf) are missing (Table 1, Fig. 3). Huber (chapter
24 , this volume) reports the last major occurrence of the planktonic foraminifer Chiloguembelina cubensis, which marks the early-late Oligocene boundary at $30 \mathrm{Ma}$, between 117.15 and 118.20 mbsf. The last occurrence of seven radiolarian taxa also takes place at this lower level (Caulet, this volume). The presence of the upper hiatus is also suggested by the absence, in Site $744 \delta^{18} \mathrm{O}$ record of Cibicidoides (Fig. 2B), of an excursion of high values observed in the benthic foraminifer record of southern South Atlantic Site 689 in sediments deposited between about 28 and $30 \mathrm{Ma}$ (Kennett and Stott, 1990). There is no biostratigraphical or stable isotope evidence for the second hiatus older than $30 \mathrm{Ma}$ inferred by ${ }^{87} \mathrm{Sr} /{ }^{86} \mathrm{Sr}$ ratios. However, both gaps in the record at Site 744 correlate with the widespread deep-sea hiatuses at 28.1-29.2 Ma (hiatus PHaa) and 30.3-31.4 $\mathrm{Ma}$ (hiatus $\mathrm{PHb}$ ) identified by Keller et al., (1987).

The global early Oligocene event of high $\delta^{18} \mathrm{O}$ values occurs in sediments normally magnetized and correlated with Chron C13 (35.7-35.9 Ma) at Site 744 (Fig. 2 and 3), as first reported by Oberhänsli and Tourmarkine (1985) for Site 522. At Site 744, $\delta^{18} \mathrm{O}$ values of Cibicidoides begin to increase in lowermost Oligocene sediment with the appearance of ice-rafted debris and continue to be high in lower Oligocene sediments reflecting high-latitude cooling and Antarctic glaciation (Barrera and Huber, this volume). Site $744{ }^{87} \mathrm{Sr} /{ }^{86} \mathrm{Sr}$ ratios increase (about $0.00004 / \mathrm{m}$.y) through the early Oligocene. However, based on the two lowermost data points of this section, it appears that the rate of change of seawater ${ }^{87} \mathrm{Sr} /{ }^{86} \mathrm{Sr}$ was highest (about $0.00015 / \mathrm{m}$.y.) in the earliest Oligocene, when $\delta^{18} \mathrm{O}$ values also increased rapidly (Fig. 2B). The increase in seawater ${ }^{87} \mathrm{Sr} /{ }^{86} \mathrm{Sr}$ in this interval may reflect increased weathering in Antarctica associated with continental glaciation.

\section{CONCLUSIONS}

${ }^{87} \mathrm{Sr} /{ }^{86} \mathrm{Sr}$ ratios of well-preserved early Miocene-Oligocene planktonic foraminifers from Site 744 in the southern Indian Ocean provide the highest southern latitude $\mathrm{Sr}$ isotope record of this age. These data have been calibrated with the magnetostratigraphy of this site. Ages of Site 744 sediments based on measured ${ }^{87} \mathrm{Sr} /{ }^{86} \mathrm{Sr}$ ratios were also determined using the $\mathrm{Sr}$ isotopeage equations of Miller et al. (1988) and Hess et al. (1989). There is good agreement between the calculated ages from ${ }^{87} \mathrm{Sr} /$ ${ }^{86} \mathrm{Sr}$ measurements using these equations and those derived from magnetobiostratigraphy. In addition, these equations were useful for inference of sediment ages in intervals where the paleomagnetic record is not well resolved and the biostratigraphy is inconclusive. Accordingly, stratigraphical resolution was increased in the late Oligocene section where ${ }^{87} \mathrm{Sr} /{ }^{86} \mathrm{Sr}$ ages indicate the presence of several hiatuses. Site $744{ }^{87} \mathrm{Sr} /{ }^{86} \mathrm{Sr}$ record can be used for correlation of Antarctic and low-latitude sequences and biostratigraphical zonation of foraminifers, radiolarians, diatoms, and calcareous nannofossils. This record will aid in the development of the high southern latitude biochronology.

\section{ACKNOWLEDGMENTS}

We thank the Ocean Drilling Program for providing samples, Dr. Terry Quinn for performing ${ }^{87} \mathrm{Sr} /{ }^{86} \mathrm{Sr}$ analyses and two anonymous reviewers for their useful comments. This research was supported by NSF grant DDP-8816833 to E.B.

\section{REFERENCES}

Baker, P. A., Giekes, J. M., and Elderfield, H., 1982. Diagenesis of carbonates in deep-sea sediments: evidence from $\mathrm{Sr} / \mathrm{Ca}$ ratios and interstitial dissolved $\mathrm{Sr}^{2+}$ data. J. Sediment. Petrol., 52:71-82.

Barron, J. A., Keller, G., and Dunn, D. A., 1985. A multiple microfossil biochronology for the Miocene. In Kennett, J. P. (Ed.), The Miocene Ocean: Paleoceanography and Biogeography: Cambridge (Cambridge Univ. Press), 763-805. 
Berggren, W. A., Kent, D. V., and Flynn, J. J., 1985a. Jurassic to Paleogene: Part 2. Paleogene geochronology and chronostratigraphy. In Snelling, N. J. (Ed.), The Chronology of the Geological Record. Geol. Soc. London Mem., 10:141-195.

Berggren, W. A., Kent, D. V., and Van Couvering, J. A., 1985b. The Neogene: Part 2. Neogene geochronology and chronostratigraphy. In Snelling, N. J. (Ed.), The Chronology of the Geological Record. Geol. Soc. London Mem., 10:211-260.

Broecker, W. S., and Peng, T.-H., 1982. Tracers in the Sea: Palisades, NY (Eldigio Press).

Burke, W. H, Denison, R. E., Hetherington, E. A., Koepnick, R. B., Nelson, H. F., and Otto, J. B., 1982. Variation of seawater ${ }^{87} \mathrm{Sr} /{ }^{86} \mathrm{Sr}$ throughout Phanerozoic time. Geology, 10:516-519.

Delaney, M. L., Bé, A.W.H., and Boyle, E. A., 1985. Li, Sr, Mg, and $\mathrm{Na}$ in foraminiferal calcite shells from laboratory culture, sediment traps, and sediment cores. Geochim. Cosmochim. Acta, 49:13271341.

DePaolo, D. J., 1986. Detailed record of the Neogene $\mathrm{Sr}$ isotopic evolution of seawater from DSDP Site 590B. Geology, 14:103-106.

DePaolo, D. J., and Ingram, B. L., 1985. High-resolution stratigraphy with strontium isotopes. Science, 227:938-940.

Elderfield, H., 1986. Strontium isotope stratigraphy. Palaeogeogr., $\mathrm{Pa}$ laeoclimatol., Palaeoecol., 57:71-90.

Elderfield, H., and Gieskes, J. M., 1982. Sr isotopes in interstitial waters of marine sediments from Deep Sea Drilling Project cores. $\mathrm{Na}$ ture, 300:493-497.

Elderfield, H., Gieskes, J. M., Baker, P. A., Oldfield, R. K., Hawkesworth, C. J., and Miller, R., $1982 .{ }^{87} \mathrm{Sr} /{ }^{86} \mathrm{Sr}$ and ${ }^{18} \mathrm{O} /{ }^{16} \mathrm{O}$ ratios, interstitial water chemistry and diagenesis in deep-sea carbonate sediments of the Ontong-Java Plateau. Geochim. Cosmochim. Acta, 46:22592268.

Gieskes, J. M, Elderfield, H., and Palmer, M., 1986. Strontium and its isotopic composition in interstitial waters of marine carbonate sediments. Earth Planet. Sci. Lett., 77:229-235.

Hess, J., Bender, M. L., and Schilling, J.-G., 1986. Evolution of the ratio of strontium-87 to strontium-86 in seawater from Cretaceous to Present. Science, 231:979-984.
Hess, J., Stott, L. D., Bender, M. L., Kennett, J. P., and Schilling, J. G., 1989. The Oligocene marine microfossil record: age assessments using strontium isotopes. Paleoceanography, 4:655-679.

Katz, A., Sass, E., Starinsky, A., and Holland, H. D., 1972. Strontium behavior in the aragonite-calcite transformation: an experimental study at 40-98C. Geochim. Cosmochim. Acta, 36:481-496.

Keller, G., Herbert, T., Dorsey, R., D'Hondt, S., Johnson, M., and Chi, W. R., 1987. Global distribution of late Paleogene hiatuses. Geology, 15:199-203.

Kennett, J. P., and Stott, L. D., 1990. Proteus and Proto-Oceanus: Ancestral Paleogene oceans as revealed from Antarctic stable isotopic results, ODP Leg 113. In Barker, P., Kennett, J. P., et al., Proc. ODP, Sci. Results, 113: College Station, TX (Ocean Drilling Program).

Lohman, W. H., 1986. Calcareous nannoplankton biostratigraphy of the southern Coral Sea, Tasman Sea, and southwestern Pacific Ocean. Deep Sea Drilling Project Leg 90: Neogene and Quaternary. In Kennett, J. P., von der Borch, C. C., et al., Init. Repts. DSDP, 90: Washington (U.S. Govt. Printing Office), 763-795.

Miller, K. G., Feigenson, M. D., Kent, D. V., and Olsson, R. K., 1988. Upper Eocene to Oligocene isotope $\left({ }^{87} \mathrm{Sr} /{ }^{86} \mathrm{Sr},{ }^{18} \mathrm{O},{ }^{13} \mathrm{C}\right)$ standard section, Deep Sea Drilling Project Site 522. Paleoceanography, 3: 223-233.

Oberhänsli, H., and Tourmarkine, M., 1985. The Paleogene oxygen and carbon isotope history of Sites 522, 523, and 524 from the central South Atlantic. In Hs, K. J., and Weissert, H. J. (Eds.), South Atlantic Paleoceanography: New York (Cambridge Univ. Press), 125147.

Palmer, M. R., and Elderfield, H., 1985. The $\mathrm{Sr}$ isotopic composition of seawater over the past 75 Myr. Nature, 314:526-528.

Woodruff, F., and Savin, S. M., 1989. Miocene Deepwater oceanography. Paleoceanography, 4:87-140.

Date of initial receipt: 2 February 1990

Date of acceptance: 21 June 1990

Ms 119B-211 

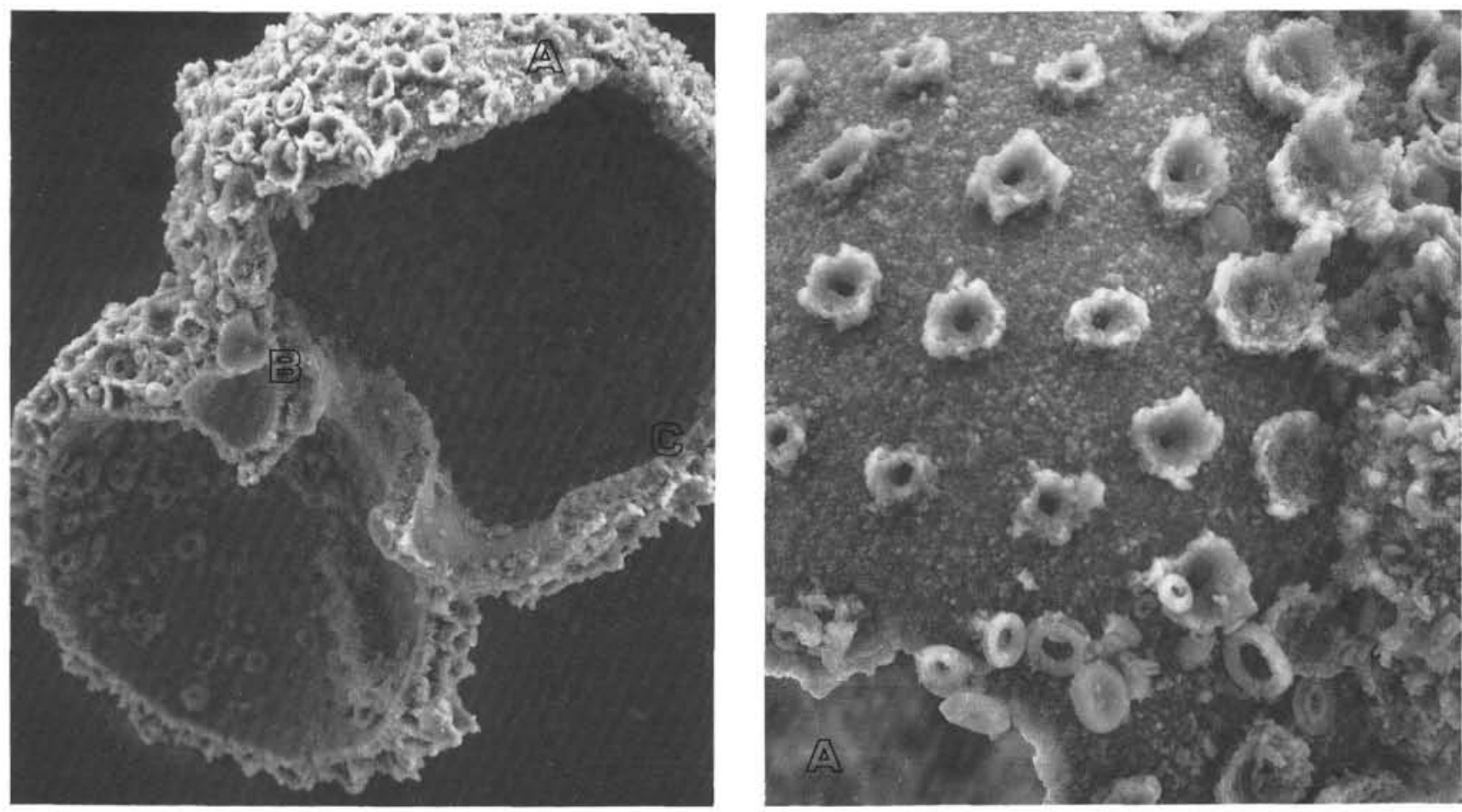

\section{1}
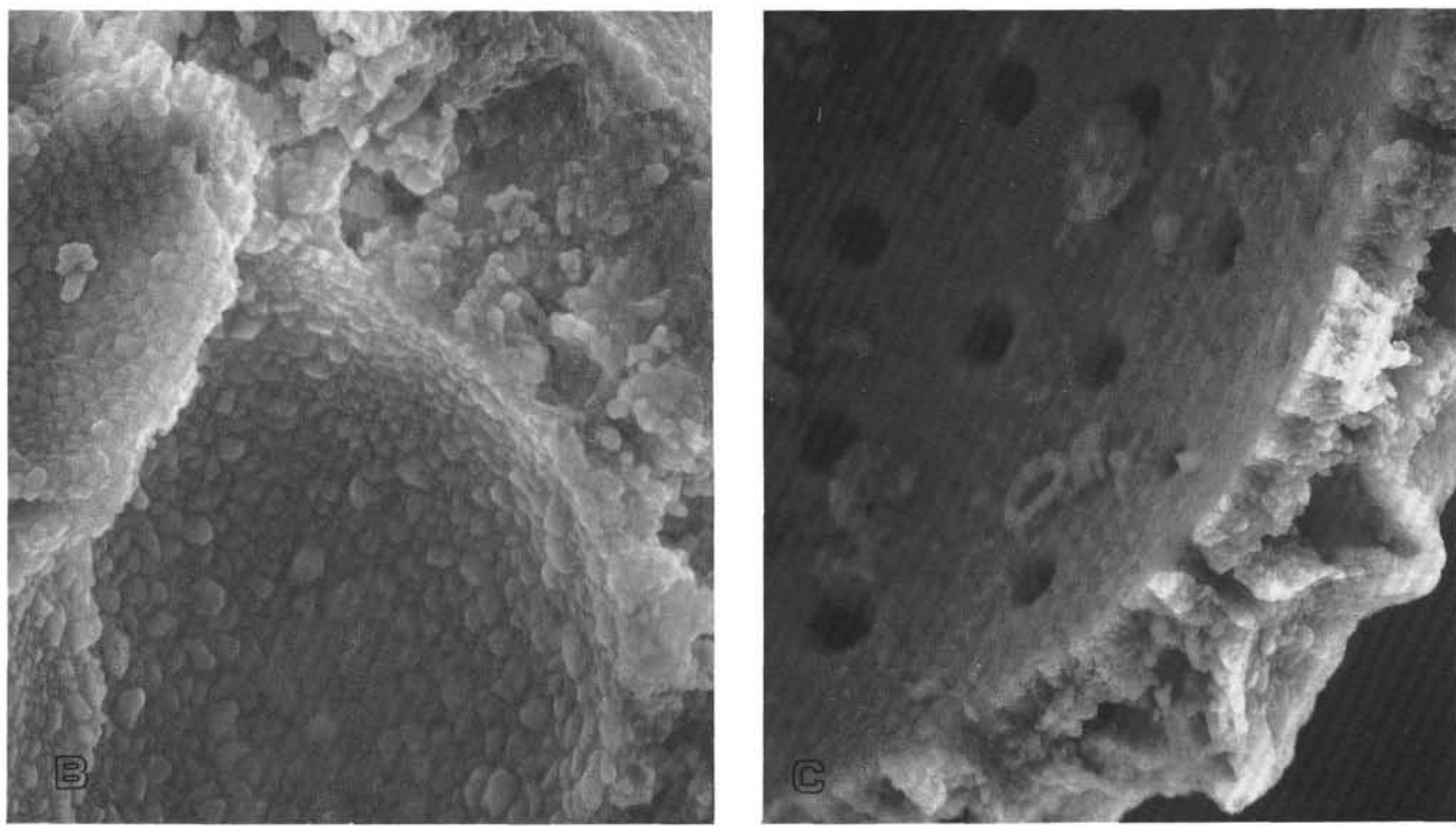

4

Plate 1. 1. Fragment of test of Globorotaloides suteri from Sample 119-744A-18-1, 95-100 cm. Bar scale $=80 \mu \mathrm{m}$. Areas of the test shown in Figs. 2, 3, and 4 are indicated with the letters A, B, and C, respectively. 2. Close view of area A in Fig. 1 showing removal of the outer layer of the test as a result of calcite dissolution within the wall. Solution features are also seen in shields of coccolithophores. Bar scale $=30 \mu \mathrm{m}$. 3. Close view of area B in Fig. 1 showing small overgrowth (euhedral) calcite crystals on interior surface of chambers in the juvenile part of the test. Bar scale $=10 \mu \mathrm{m}$. 4. Close view of area $\mathrm{C}$ in Fig. 1 showing dissolution within the wall evident in the area between the inner and outer layer. Interior surface of chamber is free of calcite overgrowth crystals. Bar scale $=15 \mu \mathrm{m}$. 